\section{Decision making in forest road planning considering both skidding and road costs: a case study in the Hyrcanian Forest in Iran}

\author{
Meghdad Jourgholami ${ }^{(1)}$, Ehsan Abdi ${ }^{(1)}$, Woodam Chung ${ }^{(2)}$
}

Hyrcanian forest is the only forest designated for commercial timber production in Iran. Ground-based skidding is the most common extraction system used in the forest, though large parts of the forest are still inaccessible due to the low road density (1-2 $\left.\mathrm{m} \mathrm{ha}^{-1}\right)$. To facilitate timber harvesting in the forest, it has been proposed to increase the road density up to $20 \mathrm{~m} \mathrm{ha}^{-1}$. The aim of this study was to incorporate the estimated skidding costs through a time study into an existing transportation planning tool, NETWORK 2000, to help decision making on forest road building. We applied this method to the Gorazbon district in the Hyrcanian forest, where 244 links were built for the analysis. The best solution found by NETWORK 2000 indicates that all the proposed roads should be built to minimize the total skidding and road building costs.

Keywords: Forest Road Network, Optimization, NETWORK 2000, Fixed Cost, Variable Costs

\section{Introduction}

Forest road building and timber harvesting are important parts of forest management activities. The Hyrcanian forest is the only commercial forest in Iran with an area of 1.9 millions ha. Ground-based skidding system is the most common mechanized timber harvesting system that has been used in Iran. The system is the process of extracting felled trees from the cutting site to a landing or roadside where the trees are processed into logs and loaded onto trucks for further transport to the sawmill. Many studies have been carried out on productivity and cost of timber harvesting, as well as influencing factors that affect the performance of each harvesting machinery (Miyata 1980, Meng 1984

$\square$ (1) Department of Forestry and Forest Economics, Faculty of Natural Resources, University of Tehran, Karaj (Iran); (2) Department of Forest Management, College of Forestry and Conservation, University of Montana, Missoula (USA)

(a) Meghdad Jourgholami (mjgholami@ut.ac.ir)

Received: Aug 13, 2012 - Accepted: Nov 06, 2012

Citation: Jourgholami M, Abdi E, Chung W, 2013. Decision making in forest road planning considering both skidding and road costs: a case study in the Hyrcanian Forest in Iran. iForest 6: 59-64 [online 2013-01-21] URL: http://www.sisef.it/iforest/contents? id=efor0640-006

Communicated by: Marco Borghetti
Lanford et al. 1990, Abeli 1993, Bjorheden \& Thompson 1995, McDonald 1999, McDonald \& Rummer 2002, Wang \& Haarlaa 2002, Egan \& Baumgas 2003, Wang 2003, Akay et al. 2004, Picchio et al. 2011, Spinelli \& Magagnotti 2012). In north of Iran, Sobhani \& Stuart (1991) evaluated the harvesting system with a Clark 66BDS wheeled skidder, and several researchers have studied the productivity and cost of skidding operations (Feghhi 1989, Naghdi 2004).

The road density in the forest is currently very low, ranging between 1 and $2 \mathrm{~m} \mathrm{ha}^{-1}$. To improve accessibility and facilitate timber harvesting in the forest, it has been proposed to increase the road density up to 20 $\mathrm{m} \mathrm{ha}^{-1}$ (Iranian Plan and Budget Organization 2000). Therefore, an extensive road planning and construction will take place in the forest to facilitate management activities and timber harvesting that can produce required wood for the country.

Roads are an essential structure that provides access to the forest for a variety of activities such as logging operation, recreation and firefighting. The profitability of timber harvesting is largely influenced by road network structure (Murray 1998, Spinelli et al. 2007, Cavalli \& Grigolato 2010), and thus it is important that roads are properly planned to ensure the cost-effective transport of forest products, as well as to provide safe and comfort vehicle operations (Abeli et al. 2000). However, planning a proper road network to access timber harvest sites is a difficult and time-consuming task. Road networks are currently designed ma- nually using contour and thematic maps (Liu \& Sessions 1993, Rogers 2005), but the manual approach might result in an inefficient network because only limited number of alternatives can be examined (Chung et al. 2008, Abdi et al. 2009). Therefore, the development of a methodology for the identification of current and future access needs, as well as the selection of the optimal road network from an economic point of viewpoint, are still a fundamental area of research (Murray 1998, Spinelli et al. 2007, Cavalli \& Grigolato 2010). For the Hyrcanian forest, the need for tools and techniques to assist in the development of road network systems in the forest, particularly in the context of accessing timber harvest sites, it has been well identified (Iranian Plan and Budget Organization 2000).

The aim of this study is to estimate skidding costs from the results of a time study and incorporate the estimated road and skidding costs into an existing transportation planning tool, NETWORK 2000 (Chung \& Sessions 2003), to select a cost effective road network that minimizes the total skidding and road building costs. We applied this method to the Gorazbon district in the Hyrcanian forest, where 244 links were built for the analysis. Detailed methods and application results are presented below.

\section{Material and methods}

\section{Study Area}

The study was carried out in the Gorazbon district in the Hyrcanian forest, which is a part of the Educational and Experimental Forest of University of Tehran (Fig. 1). It is located on northern slopes of Elbourz Mountains, about $7 \mathrm{~km}$ from Nowshahr $\left(36^{\circ} 33^{\prime}\right.$ N, $\left.50^{\circ} 33^{\prime} \mathrm{E}\right)$. The district covers about 1000 hectares and its elevation ranges from 550 to $1380 \mathrm{~m}$ a.s.l. Ground slopes range between 0 to 115 percentages, and the average slope in the whole district is about 15 percentage. This area was dominated by natural forests containing native mixed deciduous tree species such as Fagus orientalis Lipsky, Carpinus betulus L. and Acer velutinum Boiss. A mixed uneven-aged management system with single and group selection harvesting has been used in this district, resulting in an average growing stock of $338 \mathrm{~m}^{3} \mathrm{ha}^{-1}$ in a multistory forest structure. Selected trees for harvesting are felled by chainsaws, limbed and topped at the stump with a crew consisting of two men (chainsawer and coworker). Felled trees are bucked with chainsaws into saw logs (with diameters $>30 \mathrm{~cm}$ ) and pulp $\operatorname{logs}(<30 \mathrm{~cm})$. Logs with a 5 to 15 meter length are extracted by wheeled skidders with winch to roadside landings and the fuel woods from delimibing parts are extracted by mules. In steep terrain where skidders are 
Fig. 1 - Study area located in the Hyrcanian Forest.

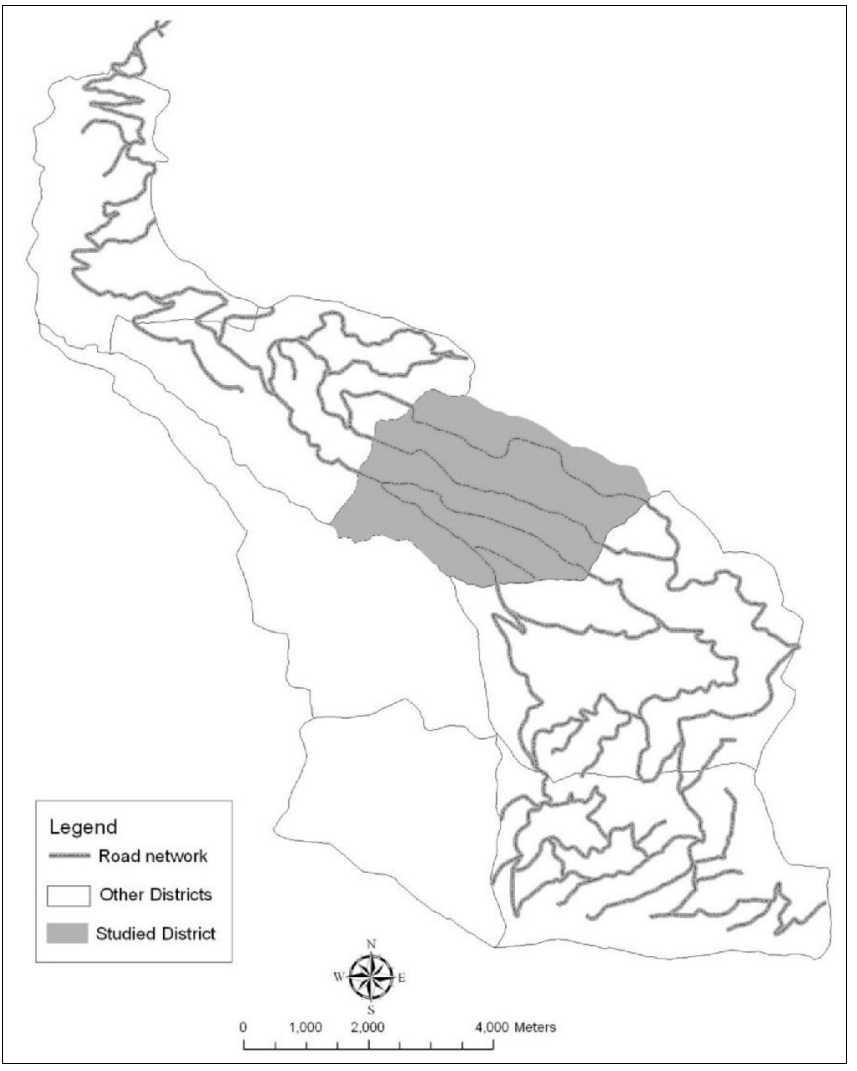

hindered, logs are processed to sawn-lumber and then hauled by mules. Sawn-lumbers (flitched lumbers) in the Hyrcanian forest region are 2.2-2.8 $\mathrm{m}$ long, $30-34 \mathrm{~cm}$ wide and $10-15 \mathrm{~cm}$ thick (Jourgholami 2012).

The total length of extant roads in the Hyrcanian district is $12.45 \mathrm{~km}$. Hence, to meet the target road density in this district $6.92 \mathrm{~km}$ of new roads have been proposed for construction in the next decade. Current forest road density is $19.4 \mathrm{~m} \mathrm{ha}^{-1}$. Forest roads are categorized as permanently main forest roads used for trucking, with an average width of $6.5 \mathrm{~m}$ and a longitudinal slope of 3 to $8 \%$ (Jourgholami 2010). Three com-

partments (301, 302 and 303), located on steep slopes and designated as protected areas, were excluded from our analysis.

\section{Data collection}

A time study was conducted to estimate skidding costs and production rate of a Timberjack 450C skidder during June and July of 2011. This machine is normally an articulated, four-wheel-drive vehicle weighing 10.3 ton $(55 \%$ on the front and $45 \%$ on the rear axle) with engine power of $177 \mathrm{hp} \mathrm{(132}$ $\mathrm{kW}$ ) and engine model 6BTA5.9. It is equipped with a blade for light pushing of obstacles and stacking of logs. The skidder was

Tab. 1 - Estimated harvest volume in the study area. (1): Refer to Fig. 2 for map of the harvest compartments. Some compartments are split into LN1 and LN2 depending on skidding direction. (2): Year 0 indicates the current year.

\begin{tabular}{|c|c|c|c|c|c|c|c|c|}
\hline $\begin{array}{l}\text { Harvest } \\
\text { Comp. }\end{array}$ & $\begin{array}{c}\text { Volume } \\
\left(\mathrm{m}^{3}\right)\end{array}$ & Year $^{(2)}$ & $\begin{array}{l}\text { Harvest } \\
\text { Comp. }\end{array}$ & $\begin{array}{c}\text { Volume } \\
\left(\mathbf{m}^{3}\right)\end{array}$ & Year & $\begin{array}{l}\text { Harvest } \\
\text { Comp. }\end{array}$ & $\begin{array}{c}\text { Volume } \\
\left(\mathrm{m}^{3}\right)\end{array}$ & Year \\
\hline 309LN1 & 1519.6 & 0 & 313LN2 & 758.8 & 2 & 323LN1 & 2201.7 & 6 \\
\hline 307LN1 & 1349.7 & 0 & 317LN2 & 1090.8 & 3 & $327 \mathrm{LN} 1$ & 1201.2 & 6 \\
\hline 307LN2 & 490.8 & 0 & 318LN2 & 990 & 3 & 322LN1 & 999 & 6 \\
\hline 309LN2 & 681.2 & 0 & 318LN1 & 810 & 3 & 324LN1 & 2699.9 & 7 \\
\hline 310LN1 & 844.2 & 1 & 317LN1 & 969.6 & 3 & 316LN1 & 1401.3 & 7 \\
\hline 311LN1 & 632.7 & 1 & 320LN1 & 2298.3 & 4 & 319LN1 & 2499.9 & 8 \\
\hline 312LN1 & 1200.0 & 1 & 314LN1 & 728 & 4 & 305LN1 & 445.5 & 8 \\
\hline 310LN2 & 656.6 & 1 & 304LN1 & 650 & 4 & 305LN2 & 405 & 8 \\
\hline 311LN2 & 266.4 & 1 & 304LN2 & 600 & 4 & 315LN1 & 1000 & 9 \\
\hline 312LN2 & 600.0 & 1 & 314LN2 & 318.5 & 4 & 321LN1 & 2200 & 9 \\
\hline 313LN1 & 1788.6 & 2 & $325 \mathrm{LN} 1$ & 699.2 & 5 & 306LN1 & 583.8 & 9 \\
\hline 308LN1 & 1275.0 & 2 & 326LN1 & 2701.9 & 5 & 306LN2 & 166.8 & 9 \\
\hline 308LN2 & 525.0 & 2 & - & - & - & - & - & - \\
\hline
\end{tabular}

Tab. 2 - Elements of road construction costs.

\begin{tabular}{lr}
\hline $\begin{array}{l}\text { Road construction } \\
\text { elements }\end{array}$ & $\begin{array}{c}\text { Cost (USD } \\
\text { per } \mathbf{~ k m})\end{array}$ \\
\hline Planning & 1030.9 \\
Earthwork (cut and fill) & 9278.4 \\
Subgrade construction & 24742.3 \\
Culverts and ditch & 5154.6 \\
Maintenance and repair (5\% & 2010.3 \\
of roading costs) & \\
Total & 42216.5 \\
\hline
\end{tabular}

fitted with size 24.5-32 tires inflated to 220 $\mathrm{kPa}$ on both front and rear axles. Times and operational variables were measured using a stopwatch and recorded on paper (Egan \& Baumgas 2003). The working cycle for each operation consisted of certain elemental functions and factors. The times for each function and the value of each factor were recorded in the field. The time elements measured in the skidding cycle time include travel empty, releasing winch, choker setting, winching, travel loaded, unhooking and decking. Technical, personal and operational delays were recorded during the time study up to 15 minutes. In addition to measuring skidder working cycle time, independent variables expected to affect skidder productivity were documented. The variables measured during the time study include skidding distances (meter), skid trail slope (\%), number of logs per turn, and load volume. A total of 150 working cycles were collected using the Timberjack 450C.

Timber harvest volume data and road costs were obtained from the forest management plan of the district. A total of $40249 \mathrm{~m}^{3}$ of timber is planned to be harvested in the next 10 years (Tab. 1). For road costs, we estimated an annual life cycle cost (USD year ${ }^{-1}$ ) based on the total construction cost (Tab. 2), an interest rate of $5 \%$, and a life cycle time period of 50 years. The interest on investment and the depreciation cost during the life cycle time period were calculated as USD 844 and USD 2.111 per year per km, respectively. The annual life cycle cost was thus estimated at USD 2.955 per km. Also, the truck transportation cost per cubic meter as the variable cost in the study area was assumed to be USD 0.31 per $\mathrm{km}$.

\section{Using NETWORK 2000}

Forest road network planning typically involves decision making on road locations that provides access to pre-determined harvesting sites (i.e., landings) in a way that minimizes overall road building and timber harvesting costs. Matthews (1942) presented a theoretical model of the optimum road network that minimizes both skidding and road costs, but the model applications have been limited due to the fact that forest roads are 
not always parallel (Chung et al. 2008). Road network planning is often done manually, but some mathematical optimization techniques, such as mixed integer programming and heuristics, have been also used to solve road network location problems (Ghafarrian \& Sobhani 2007)

NETWORK 2000, a timber transportation planning tool, is a software helping to solve the network planning problems. The tool employs a heuristic network algorithm to quickly solve large fixed and variable cost road network problems (Chung \& Sessions 2003). Ghafarrian \& Sobhani (2007) used this software to decide which segments of road network should be eliminated to minimize total transportation costs. NETWORK 2000 requires two datasets: link data and sale data. Link data consists of information on each link in a road network including from node, to node, fixed cost, and variable cost. Links can represent existing roads, proposed roads, or flows of timber volume to a landing site where a harvest unit (compartment) is connected to the road network. If a link represents a timber volume flow to a landing site, harvesting cost per unit of volume becomes the variable cost of that link. If a link represents a proposed road, road building cost of that road becomes fixed cost. Fixed cost of a link becomes zero if the link represents an existing road. Sale data includes information on timber source (i.e., harvest compartment), destination (i.e. mill), volume, and production year. Once a road network problem is formulated based on given link and sale data, NETWORK 2000 determines the least cost routes to transport timber from its sources to the destination in the most cost-effective way. These least-cost routes, the output of NETWORK 2000 , are then used to identify which landing sites, existing roads, and proposed roads should be selected for timber harvesting activities in given harvest compartments.

The following steps were conducted before NETWORK 2000 was run. First, each of the compartments was assigned to one or more landing sites (loading nodes) which are located on the road network. Node locations were identified considering topographic conditions of each harvest compartment. These nodes represent the potential landing location where log volumes are loaded onto the road network with skidding system. Each loading node was labeled with a unique ID and connected to its compartment via an imaginary link representing a potential timber flow between the compartment and the loading node. Each harvest compartment became a timber source and a timber volume to be harvested from the compartment was ascribed. To each imaginary link connecting a compartment with its potential loading node was assigned a harvesting cost per unit

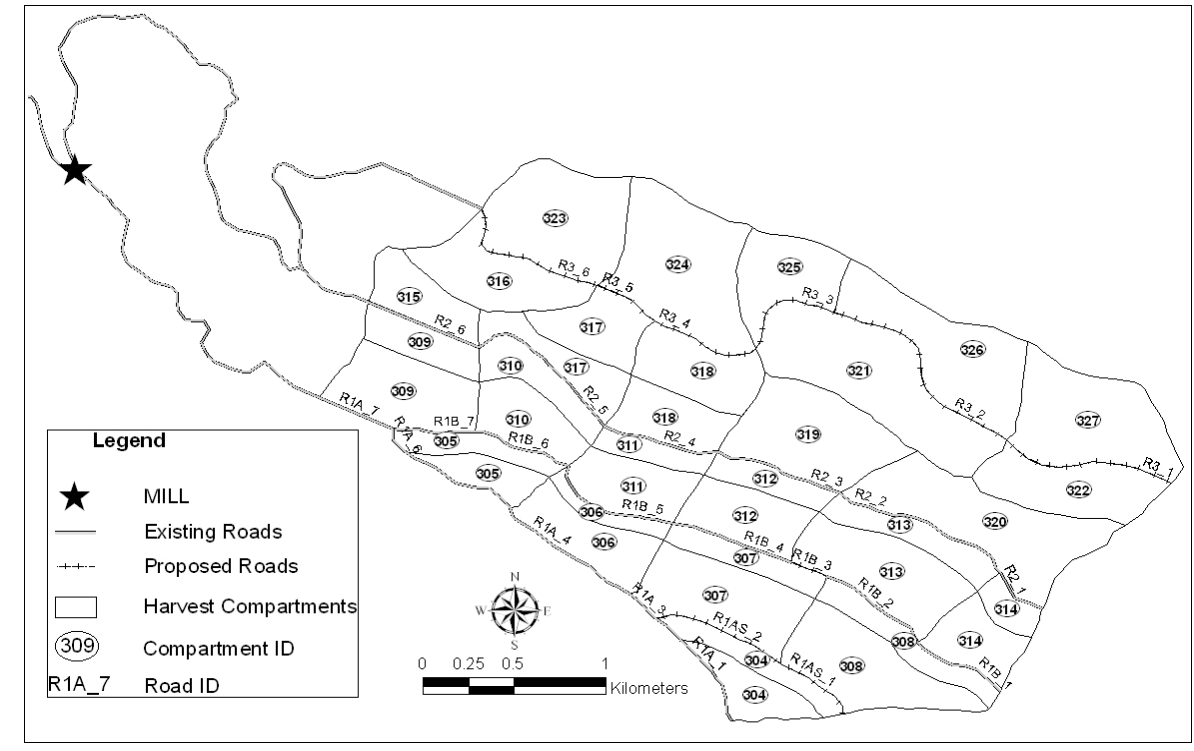

Fig. 2 - Harvest compartments and road links used in the network analysis. of volume associated with its harvesting system. Harvesting cost was estimated based on the mean skidding distance in the compartment and the results of the time study we conducted. The mean skidding distance was assumed to be the distance between the center of the compartment and the loading node (Pentek et al. 2005). As the result, a total of 244 links were built, and a total of 108 potential loading nodes were identified for 37 compartments to be harvested to produce about $40217 \mathrm{~m}^{3}$ of timber over the next 10 years (Fig. 2). NETWORK 2000 was then run on this dataset to find the most cost effective way to harvest and haul timbers for any given compartments. No discount rate was used for this network analysis.

\section{Results}

\section{Skidding cycle time}

A regression analysis with the stepwise method between independent variables (skidding distance, trail slope, number of logs, and load volume) was performed on the time study data collected for Timberjack 450C skidder. The stepwise analysis revealed that skidding distance significantly affects the skidding cycle time (Fig. 3); thus a skidding cycle time regression model was developed using skidding distance as predicting variable (eqn. 1):

$$
T=6.43235+0.02686 \cdot D
$$

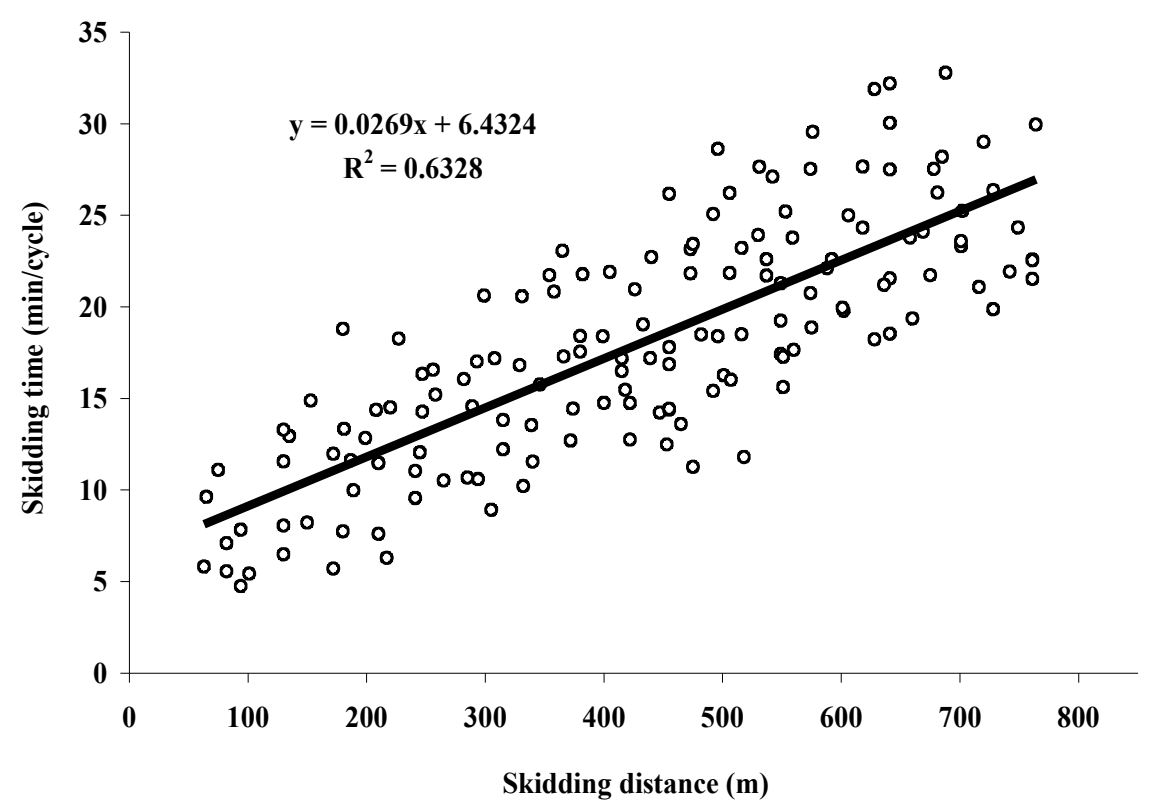

Fig. 3 - A scatter plot showing the relationship between skidding distance and cycle time. 
Tab. 3 - ANOVA table for the regression model developed for the Timberjack 450C skidder.

\begin{tabular}{lcccccc}
\hline \multicolumn{1}{c}{ Factor } & $\begin{array}{c}\text { Sum of } \\
\text { Squares }\end{array}$ & df & $\begin{array}{c}\text { Mean } \\
\text { Square }\end{array}$ & F & R & Prob \\
\hline Regression & 3956.34 & 1 & 3956.34 & 258.5 & 0.79 & $<0.0001$ \\
Residual & 2295.63 & 150 & 15.3 & - & - & - \\
Total & 6251.97 & 151 & - & - & - & - \\
\hline
\end{tabular}

Tab. 4 - Results of the $t$-test for the predicting variable.

\begin{tabular}{lccccc}
\hline \multirow{2}{*}{ Factor } & \multicolumn{2}{c}{$\begin{array}{c}\text { Unstandardized } \\
\text { Coefficients }\end{array}$} & $\begin{array}{c}\text { Standardized } \\
\text { Coefficients }\end{array}$ & \multirow{t}{*}{$\boldsymbol{c}$} & \multirow{2}{*}{ Prob } \\
\cline { 2 - 4 } & Coeff. & Std. Error & Beta & & \\
\hline Skidding distance & 0.027 & 0.002 & 0.79 & 16.07 & $<0.0001$ \\
Constant & 6.432 & 0.78 & - & 8.2 & $<0.0001$ \\
\hline
\end{tabular}

Tab. 5 - ANOVA table for the regression model developed for the production without delay time.

\begin{tabular}{lcccccc}
\hline \multicolumn{1}{c}{ Factor } & $\begin{array}{c}\text { Sum of } \\
\text { Squares }\end{array}$ & df & $\begin{array}{c}\text { Mean } \\
\text { Square }\end{array}$ & F & R & Prob \\
\hline Regression & 5163.76 & 1 & 5163.76 & 69.91 & 0.54 & $<0.0001$ \\
Residual & 12311.61 & 150 & 82.08 & - & - & - \\
Total & 17475.37 & 151 & - & - & - & - \\
\hline
\end{tabular}

Tab. 6 - Results of $t$-tests for the predicting variable.

\begin{tabular}{lccccc}
\hline \multirow{2}{*}{ Factor } & \multicolumn{2}{c}{$\begin{array}{c}\text { Unstandardized } \\
\text { Coefficients }\end{array}$} & $\begin{array}{c}\text { Standardized } \\
\text { Coefficients }\end{array}$ & \multirow{2}{*}{$\boldsymbol{t}$} & \multirow{2}{*}{ Prob } \\
\cline { 2 - 4 } & Coeff. & Std. Error & Beta & & \\
\hline Skidding distance & -10.04 & 1.266 & -0.544 & -7.932 & $<0.0001$ \\
Constant & 72.943 & 7.534 & - & 9.681 & $<0.0001$ \\
\hline
\end{tabular}

where $T$ is the skidding cycle time without delay $(\mathrm{min})$ and $D$ is the skidding distance (m). The multiple correlation coefficient was 0.79 and the variance accounted for by the model was $63 \%$ of the total variance. Overall goodness-of-fit was tested using a F-test $(\mathrm{p}<0.0001)$ and the significance of individual parameters by a $t$-tests (Tab. 3, Tab. 4).

Travel loaded is the most time consuming phase of the skidding operation. Similar to travel unloaded, travel loaded is strongly related to skidding distances. The results showed that the skidding distance was an important variable to construct the time consumption model of skidding cycle time.

\section{Machine productivity}

An hourly production rate $\left(P R, \mathrm{~m}^{3} \mathrm{~h}^{-1}\right)$ of the Timberjack 450C skidder was estimated using the production volume and time data collected during the time study as follows (eqn. 2):

$$
P R=\frac{T P}{T T}
$$

where $T P$ is the total extracted volume $\left(\mathrm{m}^{3}\right)$, and $T T$ represents the total machine hours.
The gross productivity (the average productivity with delay time) and the net productivity (the average productivity without delay time) of the Timberjack 450C for different distances were $8.3 \mathrm{~m}^{3} \mathrm{~h}^{-1}$ and $11.1 \mathrm{~m}^{3}$ $\mathrm{ha}^{-1}$, respectively. It was found that the production rate of the skidder decreases as skidding distance increases, but the decrease rate slows down as skidding distance exceeds $300 \mathrm{~m}$ (Fig. 4). A logarithmic regression model was chosen to describe the relationship between skidding distance and hourly production rates (delay free time - eqn. 3 ):

$$
Y=-10.04 \ln (X)+72.943
$$

where $Y$ is the net productivity $\left(\mathrm{m}^{3} \mathrm{~h}^{-1}\right)$, and $X$ is the skidding distance $(\mathrm{m})$. Overall goodness-of-fit was tested by F-test $(p<0.0001)$ and the significance of individual parameters by $t$-tests (Tab. 5, Tab. 6).

\section{Estimating skidding costs}

Estimates of hourly machine costs (USD $\mathrm{ha}^{-1}$ ) of the skidding operation were computed using the machine rate method (Miyata 1980). This machine cost was then divided by the estimated production rate $\left(\mathrm{m}^{3}\right.$ $\mathrm{ha}^{-1}$ ) at a given skidding distance to estimate skidding cost per unit of volume (USD $\mathrm{m}^{-3}$ ). A purchase price of USD 123.711 was used in the machine cost estimating model, and the annual interest rate was set at $19 \%$. A machine life of 10 years was assumed. Insurance and tax rate and utilization rate were set at $5 \%$ and $71.4 \%$, respectively. Productive Machine Hour $(P M H)$ and Scheduled Machine Hour $(S M H)$ for the skidder were considered to be 900 hours and 1260 hours, respectively, so that the utilization of the chain saw is $75 \%$ (eqn. 4). Cost calculations were based on the assumption that the machine operator works the whole year except the rainy season when the logging area is not accessible. The skidding operation was considered for a total 180 days per years (eqn. 4):

$$
U=\frac{S M H}{P M H}=71.4
$$

Labor cost for skidding operation depends on the number of persons involved in each phase, the salary of each worker and the duration of their contracts. In Iran, almost all workers in the companies are paid monthly. Hourly cost derives from monthly salary divided by annual production hours. The skidding operation using the Timberjack $450 \mathrm{C}$ typically involves a crew of three people (eqn. 5):

$$
L C=\frac{\text { Total Labor Cost }}{\text { Productive Hour }}=\frac{\text { USD } 12764}{900}=14.18
$$

Tab. 7 summarizes machine cost estimate for Timberjack 450C skidder. The hourly machine cost was estimated as USD 67.87. Unit cost of production in different work phases was calculated by dividing the system cost by the average productivity per hour (eqn. 6):

$$
U C=\frac{S C}{A P}
$$

where $U C$ is the unit cost (USD $\mathrm{m}^{-3}$ ), $S C$ is the system cost (USD hour ${ }^{-1}$ ), and $A P$ is the average productivity $\left(\mathrm{m}^{3}\right.$ hour $\left.{ }^{-1}\right)$. Hence, the skidding cost per cubic meter of timber volume including the delay time was 8.2 USD $\mathrm{m}^{-3}$, while the skidding cost without delay was estimated as $6.1 \mathrm{USD}^{-3}$. Approximately $25 \%$ of total operating hours were classified as delay times during the time study, which results in an average net productivity of $75 \%$. Fig. 5 show the distribution of elemental times per skidding with the Timberjack.

\section{NETWORK 2000 output}

The best solution obtained by the use of the software NETWORK 2000 indicates that $3.63 \mathrm{~km}$ of two new roads (one is from R3 2 to R3-6 and the other is from R1AS 2 to R1A_3 in Fig. 2) should be built to mini- 


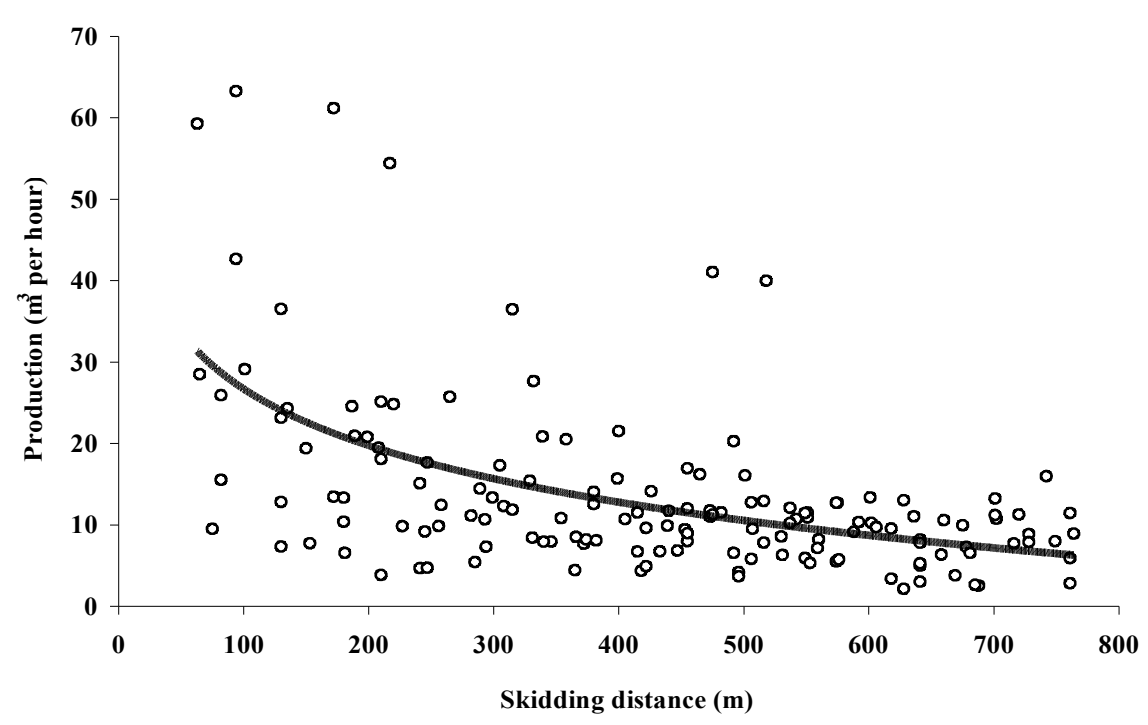

Fig. 4 - A scatter plot showing the relationship between skidding distance and hourly production rates (delay free time) of Timberjack 450C skidder.

mize both skidding and road costs. The total variable costs including skidding and haul costs is estimated as USD 340631 for harvesting $40250 \mathrm{~m}^{3}$ of timber in 37 compart-

ments, while the estimated total road cycle time cost for next 10 years is USD 101321. The average harvesting and road costs per $\mathrm{m}^{3}$ are USD 8.46 and USD 2.52, respectively.

Tab. 7 - Machine cost calculation results for Timberjack 450C.

\begin{tabular}{lcc}
\hline Cost elements & $\begin{array}{c}\text { Total Cost } \\
\text { (USD) }\end{array}$ & $\begin{array}{c}\text { Cost per hour } \\
\text { (USD) }\end{array}$ \\
\hline Fixed costs & - & 12.37 \\
Depreciation & 11134.02 & 15.13 \\
Interest & 13617.53 & 2.75 \\
Tax and Insurance & 2475.15 & - \\
Subtotal (Fixed) & 27226.7 & 30.25 \\
Operating costs & - & - \\
Maintenance and Repair & 10017 & 11.13 \\
Fuel and Lubricant & 5013 & 5.57 \\
Tires & 3294 & 3.66 \\
Cable & 2772 & 3.08 \\
Subtotal (Operating) & 2105 & 23.44 \\
Hourly labor cost & - & 14.18 \\
Total Hourly Machine Rate & - & 67.87 \\
(Fixed + Operating + Labor) & & \\
\hline
\end{tabular}

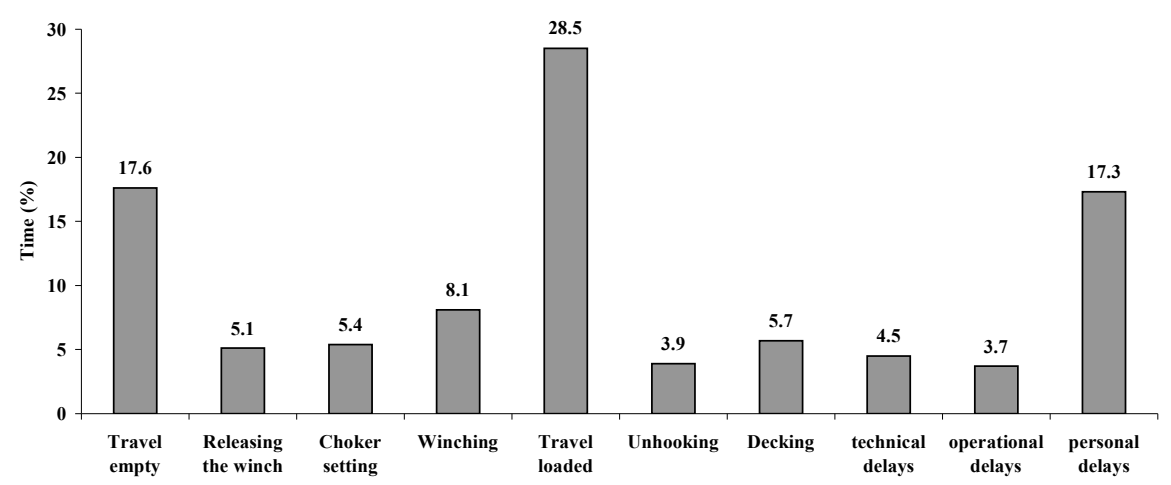

Fig. 5 - Percentage of time distribution of skidding elements.

\section{Discussion}

The production rate of Timberjack $450 \mathrm{C}$ skidder in this study was low compared to a previous study carried out in the Hyrcanian Forest (Naghdi 2004). The reason for increased skidding time and decreased production of the skidder was mainly attributable to the cut-to-length system used in this work. The major reason why the tree-length method did not apply to the study area was the low radius of forest roads. Low road radius in the Kheyrud forest did not allow truck trailers to transport tree-length timber. The study carried out by Naghdi (2004) adopted the tree-length harvesting system, with production rates for the same skidder of 13.6 and $17.1 \mathrm{~m}^{3} \mathrm{~h}^{-1}$ with and without delay, respectively. In our time study, winching logs was the most time-consuming phase ( $24 \%$ of the total operation time), even though skidding distance was the most influencing variable affecting skidding cycle time. A number of related studies (Abeli 1993, Egan \& Baumgas 2003, Wang 2003, Akay et al. 2004, Picchio et al. 2011, Spinelli \& Magagnotti 2012) reported similar findings about the primary influence of skidding distance on skidding cycle time, travel loaded time and cable skidding productivity. On the other hand, winching distances and interaction between skidding distances and the ground slope were additional important factors affecting elemental times and productivity. Wang (2003) found that travel unloaded time depends on travel distance. Time consumption in skidder roundtrip accounted for approximately $46.1 \%$ of the total gross-effective time. The reason why NETWORK 2000 does not select all the proposed roads for skidding depends on the fact that in some compartments building a road is more expensive than skidding a long distance. For example, logs produced from the lower portion of Compartment 308 (308LN1) and the upper portion of Compartment 304 (304LN2) can be directed to two landing sites: R1AS-1 and R1AS-2. For Compartment 308, the skidding cost with the R1AS-1 landing option was estimated USD 6.54 per $\mathrm{m}^{3}$, while skidding cost for the R1AS-2 option was USD 11.8 per $\mathrm{m}^{3}$ because of a longer skidding distance. However, due to relatively small harvest volume from the two compartments (total $1875 \mathrm{~m}^{3}$ ), cost savings with the R1AS-1 landing option were not sufficient to justify the additional cost (USD 17 952) related to the construction of a new road between R1AS-1 and R1AS-2.

In conclusion, we presented a methodology to support decision-making in timber harvest planning using skidding cost estimates and NETWORK 2000 software tool. We were able to identify cost effective landing and new road locations for the 37 harvest compartments in the Hyrcanian forest analyzed 
in this study. As suggested by Chung et al (2008), the heuristic network algorithm implemented in the NETWORK 2000 software does not guarantee optimal solutions, though trade-off analysis between road and skidding costs may be carried out, obtaining the overall least cost solution in road network and harvesting design. To this regard, NETWORK 2000 can be a valuable tool for forest managers who want to analyze road alternatives and select cost effective road and harvesting systems for timber management.

\section{References}

Abdi E, Majnounian B, Darvishsefat AA, Mashayekhi Z, Sessions J (2009). A GIS-MCE based model for forest road planning. Journal of Forest Science 55 (4): 171-176. [online] URL: http://www.agriculturejournals.cz/publicFiles/05 121.pdf

Abeli WS (1993). Comparing productivity and costs of three upgrading machines. International Journal of Forest Engineering 5 (1): 33-39. [online] URL: http://journals.hil.unb.ca/index.php/ IJFE/article/view/10047/10303

Abeli WS, Shemwetta TK, Ole Meiludie REL, Kachwele M (2000). Road alignment and gradient issues in the maintenance of logging roads in Tanzania. International Journal of Forest Engineering 11 (2): 151-159. [online] URL: http:// journals.hil.unb.ca/index.php/IJFE/article/viewA rticle/9931

Akay AE, Eradas O, Sessions J (2004). Determining productivity of mechanized harvesting machines. Journal of Applied Science 4 (1): 100105. - doi: 10.3923/jas.2004.100.105

Bjorheden R, Thompson MA (1995). An international nomenclature for forest work study. In: Proceeding of the "XX IUFRO World Congress". Tampere (Finland) 6-12 August 1995, pp.16.

Cavalli R, Grigolato S (2010). Influence of characteristics and extension of a forest road network on the supply cost of forest woodchips. Journal of Forest Research 15: 202-209. - doi: 10.1007/s10310-009-0170-4

Chung W, Sessions J (2003). NETWORK 2000: a program for optimizing large fixed and variable cost transportation problems. In: Proceeding of the " $24^{\text {th }}$ Council of Forest Engineering Conference" (Wang J, Wolford M, McNeel J eds). West Virginia University, Morgantown, WV, USA.
Chung W, Stuckelberger J, Aruga K, Cundy TW (2008). Forest road network design using a tradeoff analysis between skidding and road construction. Canadian Journal of Forest Research 38: 439-448. - doi: 10.1139/X07-170

Egan AF, Baumgas J (2003). Ground skidding and harvested stand attributes in Appalachain hardwood stands in West Virginia. Forest Product Journal 53 (9): 59-65.

Feghhi J (1989). Assessment of two mechanized forest harvesting systems. M.Sc. Thesis, Faculty of Natural Resources, University of Tehran, Iran, pp. 125. [in Persian]

Ghafarrian R, Sobhani H (2007). Optimization of an existing forest road network using NETWORK 2000. Croatian Journal of Forest Engineering 28 (2): 185-193. [online] URL: http://hrcak.srce.hr/file/28462

Iranian Plan and Budget Organization (2000). Forest road project guidelines no. 131 ( $2^{\text {nd }}$ edn). Office of the Deputy for Technical Affairs. Bureau of Technical Affairs and Standards, Tehran, Iran, pp. 106. [in Persian]

Jourgholami M (2010). Harvesting plan of Gorazbon district. Faculty of Natural Resources, University of Tehran, Iran, pp. 240. [in Persian]

Jourgholami M (2012). Small-scale timber harvesting: mule logging in Hyrcanian Forest. Small-scale Forestry 11(2): 255-262. - doi: 10.1007/s11842-011-9174-y

Lanford BL, Sobhani H, Stokes BJ (1990). Tree length loading production rates for southern pine. Forest Product Journal 33 (10): 120-131.

Liu K, Sessions J (1993). Preliminary planning of road systems using digital terrain models. International Journal of Forest Engineering 4: 27-32. [online] URL: http://journals.hil.unb.ca/index. php/IJFE/article/view/10052/10308

Matthews DM (1942). Cost control in the logging industry. McGraw-Hill, New York, USA, pp. 374.

McDonald T, Rummer B (2002). Automating time study of feller-buncher. In: Proceedings of the " $33^{\text {rd }}$ Annual Meeting of Council of Afforests Engineering (COFE)". Corvallis, OR, USA, pp. 17.

McDonald T (1999). Time study of harvesting equipment using GPS-derived positional data. In: Proceedings of the Conference "Forestry Engineering for Tomorrow". Edinburgh University, Edinburgh, Scotland, pp. 12.

Meng CH (1984). A model for predicting logging machine productivity. Canadian Journal of
Forest Research 14: 191-194. - doi: 10.1139/ x84-037

Miyata ES (1980). Determining fixed and operational costs of logging equipment. General Technical Report NC-55, USDA Forest Service, St. Paul, MN, USA, pp. 16.

Murray AT (1998). Route planning for harvest site access. Canadian Journal of Forest Research 28 (7): 1084-1087. - doi: 10.1139/x98-122

Naghdi R (2004). Study of optimum road density in tree length and cut to length systems. Ph.D. Thesis, Faculty of Natural Resources, University of Tarbiat Modarres, Iran, pp. 225. [in Persian]

Pentek T, Picman D, Potocnik I, Dvorscak P, Nevecerel H (2005). Analysis of an existing forest road network. Croatian Journal of Forest Engineering 26 (1): 39-50. [online] URL: http:// hrcak.srce.hr/file/6542

Picchio R, Spina R, Maesano M, Carbone F, Lo Monaco A, Marchi E (2011). Stumpage value in the short wood system for the conversion into high forest of a oak coppice. Forestry Studies in China 13 (4): 252-262. - doi: 10.1007/s11632013-0411-7

Rogers L (2005). Automating contour-based route projection for preliminary forest road designs using GIS. M.Sc. Thesis, University of Washington, DC, USA, pp. 125.

Sobhani H, Stuart WB (1991). Harvesting systems evaluation in Caspian forests. International Journal of Forest Engineering 2 (2): 21-24. [online] URL: http://journals.hil.unb.ca/index.php/IJFE/ article/viewArticle/10072

Spinelli R, Magagnotti N (2012). Wood extraction with farm tractor and sulky: estimating productivity, cost and energy consumption. Smallscale Forestry 11 (1): 73-85. - doi: 10.1007/ s11842-011-9169-8

Spinelli R, Nati C, Magagnotti N (2007). Recovering logging residues: experiences from the Italian eastern Alps. Croatian Journal of Forest Engineering 28: 1-9. [online] URL: http://hrcak.srce.hr/11549?lang=en

Wang J, Haarlaa R (2002). Production analysis of an excavator-based harvester: a case study in finnish forest operation. Forest Product Journal 53 (2): 85-90. [online] URL: http://cat.inist.fr/? aModele $=$ afficheN\&cpsidt $=13565694$

Wang J (2003). A computer-based time study system for timber harvesting operations. Forest Product Journal 53 (3): 47-53. [online] URL: http://www.freepatentsonline.com/article/ForestProducts-Journal/99326210.html 